\title{
A scoping review of admission criteria and selection methods in nursing education
}

Vahid Zamanzadeh', Akram Ghahramanian', Leila Valizadeh², Farzaneh Bagheriyeh ${ }^{1 *}$ (D) and Marita Lynagh ${ }^{3}$

\begin{abstract}
Background: Nursing education institutions are required to select and train applicants who have appropriate characteristics for delivering effective healthcare. Unlike other healthcare professions and despite the need to attract and select a competent workforce, there has been no comprehensive analysis of the selection criteria and methods used to recruit nursing students. As there is relatively limited prior research available, we conducted a scoping review to explore and synthesise the existing evidence regarding admission criteria and selection methods of nursing students and for the purpose of identifying an agenda for future research in this field.

Methods: Our scoping review follows the Arksey and O'Malley five-step proposition including identifying the research question and relevant studies, study selection, tabulation of data, and summarizing and reporting the results. Seven databases (PubMed, CINAHL, Scopus, ERIC, SID, Irandoc and PsycINFO) were searched systematically using relevant keywords. Articles on admission of undergraduate nursing students published in both English and/or Persian from 2006 to 2019 were retrieved.

Results: Existing research evidence suggests that nursing students are largely selected on the basis of two criteria "cognitive-academic abilities" and "non-cognitive abilities." Cognitive-academic abilities were assessed in four main dimensions of mathematics, language, natural sciences and reasoning skills mainly through standardized tests and academic records. Our review shows a wide range of non-cognitive characteristics are evaluated in nursing applicants including: morality, interpersonal communication skills and psychological strength. The selection method most commonly used to assess characteristics was through interviews (panel interviews or multiple mini interviews). Other methods included references, personal statements and personality assessment tools.

Conclusions: This is the first scoping review of literature regarding nursing education selection and recruitment. Results can be used to inform nursing education policymakers and institutions in the design of their selection practices. Future research should concentrate on the evaluation and improvement methods of student selection including content and predictive validity analysis of multiple mini interview and standardized tests, development of cost-effective selection methods and job analysis studies to identify specific non-cognitive characteristics for nursing.
\end{abstract}

Keywords: Admission criteria, Selection methods, Nursing student selection, Nursing education

\footnotetext{
*Correspondence: fbagheriyeh95@gmail.com

${ }^{1}$ Department of Medical Surgical Nursing, School of Nursing and Midwifery,

Tabriz University of Medical Sciences, Tabriz, Iran

Full list of author information is available at the end of the article
}

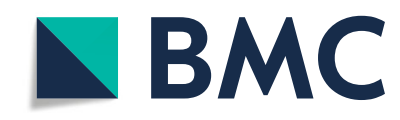

(c) The Author(s). 2020 Open Access This article is licensed under a Creative Commons Attribution 4.0 International License, which permits use, sharing, adaptation, distribution and reproduction in any medium or format, as long as you give appropriate credit to the original author(s) and the source, provide a link to the Creative Commons licence, and indicate if changes were made. The images or other third party material in this article are included in the article's Creative Commons licence, unless indicated otherwise in a credit line to the material. If material is not included in the article's Creative Commons licence and your intended use is not permitted by statutory regulation or exceeds the permitted use, you will need to obtain permission directly from the copyright holder. To view a copy of this licence, visit http://creativecommons.org/licenses/by/4.0/. The Creative Commons Public Domain Dedication waiver (http://creativecommons.org/publicdomain/zero/1.0/) applies to the data made available in this article, unless otherwise stated in a credit line to the data. 


\section{Background}

Student selection in the health professions is increasingly being recognised as an important issue [1]. The ultimate goal of student selection is to identify who will go on to be the most effective clinicians in delivering patient care, which ultimately relates to positive health outcomes [2]. Selection of students who can successfully complete their education and have necessary professional qualifications is currently considered a main challenge of health education institutions in the world [3].

Nurses, who play a key role in promoting individual and community health [4], comprise the largest group of health care workforce [5] with approximately 35 million nurses and midwives worldwide. Choosing the right student for the nursing profession will ensure job compatibility, improves nursing workforce performance in the future and ensures the safety and well-being of patients [6]. Additionally it maximizes the effectiveness of health systems and can ultimately lead to improved nursing care. It also helps to better the public image of the nursing profession in the society [7].

Recently, the number of nursing program applications has increased both internationally and in Iran $[8,9]$. One of the major challenges in the nursing education is selecting competent applicants who are most likely to accomplish the training program successfully, and make a long-term effective contribution to their profession, the general public, and the community [10]. This issue has received much attention in recent years, largely due to growing concerns of diminishing quality of nursing care, high attrition rates, limited resources and students' academic failure [11-13]. In addition, nursing instructors and educators [14] have reported a rise in unprofessional attitudes and behaviours of nursing students, further demonstrating the need for the assessment of the professional skills of applicants to nursing, in addition to academic performance [7].

\section{Selection for nursing education in Iran}

Selection methods for entering the nursing profession is considered a key nursing challenge in Iran. Currently, the fit between nursing applicants' personal characteristics and requirements of the nursing profession are not considered. This has reduced the efficiency of nurses' performance and impeded the development and maintenance of a sustained, efficient workforce $[15,16]$. Since the 1980 s, the only criterion utilised in Iran has been success in the University Entrance Exam, which takes the format of a multiple choice written test [17]. A large number of graduated from high school sit the entrance exam annually and admit different majors based on their ranks in this exam [18]. This exam caters for all majors, and hence it cannot take specific features and perquisites for each profession into account [19], where arguably criteria for the health professions may be different to other disciplines and professions.

Several obstacles have impacted the nursing student admission system and nursing profession in Iran in recent years. A significant number of high school graduates admitted to nursing schools through the current system leave before completion because of the mismatch between their personal traits and those required by the nursing profession or they lack sufficient motivation to become qualified nurses [20]. Another important negative effect is reduced efficiency and effectiveness of nurses in their job duties, which is often attributed to sub-optimal selection. In most cases, failure of individuals to effectively perform their job in the organization arises from inconsistency of their psychological characteristics with the job they are undertaking rather than the lack of technical skills or intelligence [21]. This can lead to reduced satisfaction, job failure [22], increased job burnout, decreased performance [21] and reduction of nursing care quality [23].

Nursing education institutions are responsible for selecting and training applicants who have the characteristics necessary for developing and transforming the future of the nursing profession [24, 25]. They are required to have clear admission policies relating to the selection process and minimum admission criteria [26]. However, there is a Lack of information based on research evidence regarding nursing students' admission criteria and selection practices. Given this knowledge gap and the importance of selecting the right candidates for entry into the nursing profession, a comprehensive analysis of existing research on admission criteria and selection methods of undergraduate nursing students was conducted.

\section{Objectives and review questions}

This study aimed to review existing research evidence regarding nursing students' selection criteria and selection methods. The research questions were:

1) What criteria are being used to select applicants?

2) Which selection methods are being used to assess applicants as part of selection into undergraduate nursing students?

3) What does the evidence show regarding the predictive validity of selection methods with students' academic performance?

\section{Method}

Study design

This scoping review was conducted based on the PRIS MA guidelines (see the supplementary data 1) [27, 28]. The five steps included: identifying the research 
questions; identifying relevant studies; study selection; tabulation of data; and collating, summarizing and reporting the results [29].

\section{Search strategy}

Systematic searches were conducted in databases from April to August 2019 by two researchers. Preliminary searches on PubMed and CINAHL for student selection criteria and methods were performed using the keywords "criteria", "selection methods", "nursing school", "admission criteria" and "nursing student." The title and abstract of articles were reviewed and new keywords were identified for the full article search. The final search was performed using the following keywords in PubMed, SID, Irandoc, CINAHL, Scopus, ERIC and PsycINFO databases using the Boolean operators "OR" and "AND":

- "Criteria" OR "cognitive" OR "Non cognitive" OR "admission criteria"

- "nursing student" OR "nursing application" OR "nursing education" OR nursing candidate

- "selection" OR "admission" OR "entry" OR "entrance" OR "recruitment" OR "prerequisite"

- "selection methods" OR "Selection process"

- "test" OR "interview" OR "predictive" OR "psychometric" OR "personality" OR "emotional intelligence" OR "aptitude test" OR "academic record" OR "academic attainment" OR

"performance" OR "success"

Search for Persian Literature had no result. The references of the selected articles were also searched manually.

\section{Study selection}

Studies were selected according to inclusion and exclusion criteria. Inclusion criteria were Persian and English articles on admission of undergraduate nursing students published from 2006 to 2019. Commentaries, editorials and opinion papers were excluded. The title, abstract and full text of the articles was reviewed by four researchers (VZ, AG, LV AND FB) according to the inclusion and exclusion criteria. Any disagreements resolved by discussion and consensus with the research team. The flow diagram for the article selection process is summarized in Fig. 1.

\section{Data extraction}

Key information extracted from included articles included the author, year, country, main purpose, participants, study design and main results by two reviewers. The data chart was performed independently by two reviewers and then the results were discussed. Data charting was continuously updated in an iterative process (Table 1). The extracted data then were analyzed and interpreted.

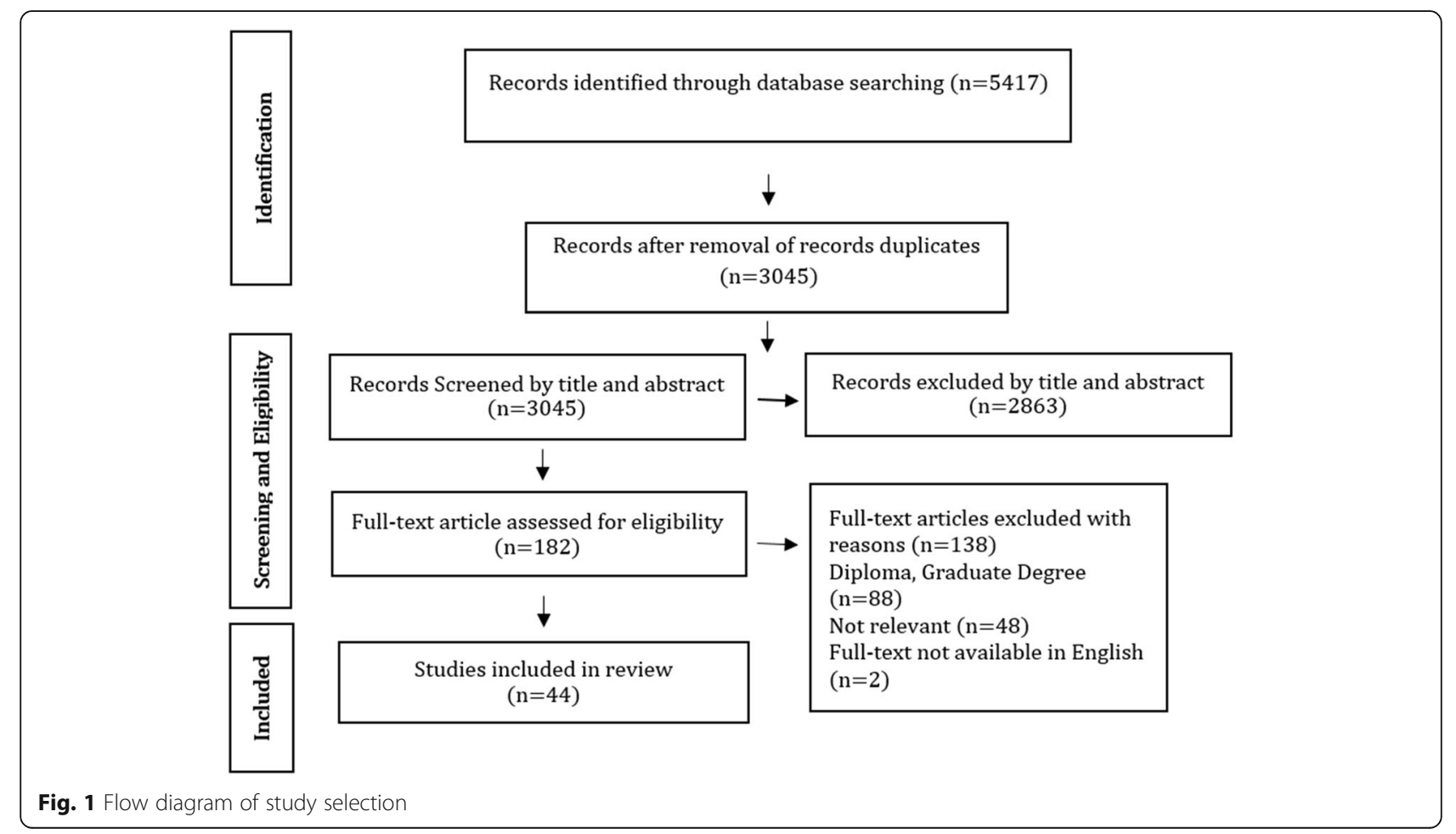


Table 1 Study characteristics of included articles $(N=44)$

\begin{tabular}{|c|c|c|c|}
\hline $\begin{array}{l}\text { Author, } \\
\text { year, } \\
\text { Country, } \\
\text { article type }\end{array}$ & Purpose & Participants & Main study findings \\
\hline
\end{tabular}

article type

Stuenkel To explore the predictive value 2006. USA [30]. Research article of various standardized examinations and achievement measures for NCLEX (National Council Licensure ExaminationRegistered Nurse) performance.

Newton To explore predictive value of et al. 2007, USA [31]. Research article scholastic and nursing aptitude of early academic achievement in a BSN (Bachelor of Science in Nursing) program

Hayes 2007, A qualitative descriptive study Canada [32]. designed to explore the nature Research article of recruitment practices for basic baccalaureate degree nursing programs in Ontario

312 BSN students from 6 graduating classes who took the NCLEX for the first time (1997-2001).

164 sophomore nursing students.

Exploratory descriptive design

15 interviews of nursing faculty and institutional liaison officers, and relevant database materials

Whitehead et al. 2007, UK [33] Research article
To identify of factors necessary for recruitment and selection of nursing students
106 students from three secondary schools

mixed methods

Qualitative descriptive design

\section{4 nursing students}

A crosssectional design

Amman [14]. study nursing with the Chance Research of Success in Nursing

article

Newton and To describe the relationships Moore 2009, among scholastic aptitude, USA [34] nursing aptitude, BSN student Research attrition prior to the final article semester, and BSN student readiness for the NCLEX-RN.

McGahee et al. 2010, USA [35]. Research article

Wolkowitz \& Kelley 2010. USA [36] Research article

Timer \& Clauson. Does the admission process give reliable, valid and fair method of 2011, Canada predicting students's succession [8] in regard to under-graduate
249 students admitted to a Canadian accelerated baccalau-reate nursing program over a 4 year design

153 graduates of BSN period of 3 years between design fall 2006 and spring 2009.

4105 RN students design characteristics in the selection process (caring, good communication skills, helpful, patient, friendly, understanding and supportive, good social skills, kind, determination/physically strong, trustworthy, considerate, able to give advice, reliable, able to stand the sight of blood, considerate, altruistic, responsible, able to cope with death, open-minded.

School grades and students' desire to study nursing are recommended as an admission criteria for potential success in nursing programs the choice to study nursing based on desire was able to predict that students will be more satisfied with studying nursing

94 BSN students. Exploratory descriptive

The final model indicated that scholastic aptitude was predictive of NCLEX-RN readiness but nursing aptitude was not. Neither scholastic nor nursing aptitude predicted student attrition.

Retrospective Science GPA (prior to admission, incl. correlational Anatomy, Physiology, Chemistry) predicts

correlational

Strongest predictor of early BSN nursing program success was science subtest, followed by reading, written/verbal, and mathematics. $14.9 \%$ of the variance in predicting early nursing program success was explained by the science sub score alone.

Retrospective Among the selection methods, only correlational academic records were able to predict design students' academic success. 
Table 1 Study characteristics of included articles $(N=44)$ (Continued)

Author, Purpose Participants
year,
$\begin{aligned} & \text { Country, } \\ & \text { article type }\end{aligned}$

article type

$\begin{array}{ll}\begin{array}{l}\text { Research } \\ \text { article }\end{array} & \begin{array}{l}\text { academic and clinical courses } \\ \text { and also the GPA? }\end{array} \\ \begin{array}{ll}\text { Schmidt \& } & \text { A systematic review of mostly } \\ \text { MacWilliams. } & \text { used admission criteria for } \\ \text { 2011, USA } & \text { prelicensure nursing programs } \\ \text { [37]. } & \text { and the relationship between } \\ \text { Review } & \text { these criteria and success in } \\ \text { article } & \text { nursing undergraduate pro- } \\ & \text { grams. }\end{array}\end{array}$

Shulruf et al. The study focused on and high2011, New lighted the predictive value of Zealand [38]. Undergraduate Grade Point Research Average as the best predictors article for student achievements in their first year in undergraduate program

Hernandez To examine the relationships

2011. USA

[39]. between quantifiable cognitive

Doctoral preadmission variables and BSN dissertation
Dante et al. To define the factors associated

2011,

Australia [40].

Research

article

Grossbach \& To examine the power of key

Kuncel 2011, admission and nursing school

USA [41]. variables for predicting NCLEX-

Research RN.

article

Pitt et al.

2012,

Australia [42] academic performance, clinical

Review performance and attrition.

article

Jarmulowicz To examine the admission

2012, USA

[43].

Doctoral

dissertation requirements of nursing programs to better understand
the philosophical underpinnings study period.

Review from different articles.

review

134 students in the undergraduate nursing program in the University of Auckland

275 nursing students.

Longitudinal design

Retrospective correlational design

design

\section{more strongly than GPA. TEAS} composite and Science section were especially strong predictors of student success. TEAS composite score is strongly related to Fundamentals test benchmarking midway through the nursing program. Student withdrawal is significantly correlated with the TEAS Composite score.

117 nursing students enrolled in years 2004-05 on two different bachelor's courses.

7159 participants yielded correlation estimates for 13 different predictors
44 articles
13 BSN student handbooks and academic bulletins, extraction of admission criteria. 33 full- time teachers integrative
review

Retrospective correlational design

meta-analysis Having good entry exam scores was associated with academic success. Descriptive correlational design
SAT and ACT predicted passing the NCLEX-RN. Prenursing (GPA) was also predictive, but to a lesser extent.

The most important influencing factors include: demographic characteristics, academic status, cognitive and personality / behavioral factors.

35 admission criteria were used by nurse education programs. All education programs shared dual admission process (university admission followed by nursing program admission) and high school transcripts. Admission criteria for baccalaureate degree programs ranged from eight to 13 criteria

Prerequisite courses of Human Nutrition, 
Table 1 Study characteristics of included articles $(N=44)$ (Continued)

\section{Author, Purpose Participants Design Main study findings \\ year, \\ Country, \\ article type}

USA [44]

Doctoral

dissertation

selection, preparation, retention

undergraduate pre-licensure clin-

ical nursing students

Rodgers

et al. 2013,

UK [45].

Research

article

Identification of best practices in

recruitment, selection and

retention across Scottish

universities providing pre-

registration programs. and graduation of

enrolled in 2007 and in stated 2008

10 universities

descriptive

design
Not applicable

A review of the challenges facing nursing and medical curricular including admission requirements; suggestions about improving admission methods and teaching strategies.

Perkins et al. How effective is Multiple Mini 2013, UK [47]. Research Interviews al as a selection too for entry into a nursing programme.

article

Usher et al. o explore the motivations of

2013, o explore the motivations of
student nurses enrolled in

Australia [48]. nursing courses

Research

article

Lancia et al. To investigate the role in 2013, Italiy predicting nursing students' [49]. Research article
Assessment of St. George's university 890 applicants and 82 Interviewers

152 nursing students

1006 BSN students (five cohorts), matriculated in consecutive academic years from 2004 to 2008
Literature review

\section{descriptive} design

qualitative descriptive design

retrospective observational study

Two groups of students, a Descriptive pre-nursing student group $(n=44)$ and a seUSA [50].

Doctoral dissertation

To describe and compare reading comprehension of two groups of students, a prenursing student group and a senior nursing student group.

Underwood To evaluate the use of HESI et al. 2013, USA [51]. Research article

Taylor et al. Explore the literature regarding 2014, UK

[52]. Research article
Admission Assessment (A2) exam as a predictor of student success. the efficacy, reliability and validity of face to face interviewing and related selection processes as selection tools

Ascertain the views/perceptions of key stakeholders in relation to the selection process nior nursing student group $(n=44)$.

184 BSN students.

7 higher institutions of higher education in Scotland with students, administration and clinical interviews participating.
Clinical Healthcare Ethics, and Human Pathophysiology were predictive of completing the program in the four terms. NET scores did not predict program completion.

GPA best reliable success predictor in nursing and other healthcare professions.

Assessing personal attributes by interview despite poor predictive reliability

Use of personal statements to examine the reasons for applicants to enter the field

A minimum GPA requirement for entry to nursing school

Scholastic Achievement Test (SAT)

American College Test (ACT)

Recommendation letters

Written essays

More than $90 \%$ of participants preferred the $\mathrm{MMI}$ method, $65 \%$ preferred the $\mathrm{MMI}$ method over traditional interviews.

The predictive validity of the MMI method is greater than that of traditional interviews.

to improve recruitment strategies in the future by assessing the applicants' personal characteristics, such as helping others (Reduce the suffering of the people, educating people about the disease, care of people)

The upper-secondary diploma coursework grades, unlike the admission test score, correlates positively with final degree grades and GPA of exam scores. Students who did not graduate within 6 semesters had lowest grades concerning their upper-secondary diploma coursework un like the admission test score.

Pre-nursing and senior nursing students scored below the standardization norms for comparable college students, and senior nursing students also scored below the standardization values for other health profession students at a comparable level of education.

Design not stated

HESI scores predicted the final course grades in all of the three first-semester nursing courses. As the HESI scores in creased, so did the final course grades.

mixed methods Lack of research evidence regarding the validity and reliability of student selection methods, especially interviews

Disagreement about the characteristics of applicants to enter the field assessing the non-cognitive and academic characteristics of applicants with different approaches (MMI, Personal statements, motivational letters, Literacy and numerical 
Table 1 Study characteristics of included articles $(N=44)$ (Continued)

Author, Purpose
year,
Country,
article type

Jones-

Schenk \&

To determine if students whose emotional intelligence

Harper. 2014, characteristics meet or exceed

USA [53]. those of successful staff nurses

Research are more likely to be successful

article in a baccalaureate nursing program.

Waugh et al. To identify potential attributes

2014, UK and key skills for entering the

[54]. field of nursing and midwifery

Research

article

Bremner To identify students most likely

et al. 2014, to succeed in nursing studies

USA [55] using TEAS

Research

article

Harner 2014, To examine the relationship

USA [56]. between TEAS scores and early

Doctoral academic success in a BSN

dissertation program

Hinderer To explore the HESI admission

et al. 2014, scores, preadmission cumulative

USA [57]

Doctoral

dissertation

GPA and science GPA as

predictors of progression to

nursing major and first-time success on the NCLEX-RN.

Sanneh \& Outline the currently used Mbuiya. student selection methods in

2015, Finland nursing education and other [58]. healthcare professions and

Master thesis identify any existing relationship between these methods and education outcomes.

Pitt et al. To explore entry critical thinking

2015, scores (Health Sciences

Australia [59]. Reasoning Test) in relation to

Research demographic characteristics,

article students' performance and progression

Elkins 2015, To investigate the possible USA [60].

Research

To investigate the possib completing the baccalaureate article nursing program and passing the NCLEX-RN licensure exam.

Crouch 2015, To assess Watson-Glaser Critical USA [61]. Thinking Appraisal (WGCTA), preResearch requisite GPA and the National

article League of Nursing (NLN) preadmission test as a pre-admission criterion.

MacDuff To interpret perspectives

et al. 2016, regarding on-site selection of

UK [62]. student nurses and midwives.

article

116

potential nursing

students and 42

successful staff nurses

descriptive,

correlational

design

tests, Academic qualification, Personal and group interviews)

Students with higher levels of emotional intelligence, particularly intrapersonal capacity and stress tolerance, are more likely to be successful in a baccalaureate nursing program than students with lower levels.

502 participants

survey

Consensus in the top seven ranked attributes: honesty and trustworthiness, communication skills, being a good listener, patience and tactfulness, sensitivity and compassion, good team worker and the ability to seek and act on guidance.

511 first semester A crossstudents enrolled from fall 2011 to fall 2013

sectional scriptive study

218 nursing students.

correlational study

89 nursing students admitted 2008-2010 (three cohorts)

exploratory retrospective descriptive design

17 articles

iterature Review

134 BSN students.

Longitudinal correlational study

187 BSN nursing students from two courses admitted during fall 2007 and 2008

192 first-year nursing students.

study

Correlational study

Test of Essential Academic Skills (TEAS) scores predicted

Two subcomponents of TEAS, namely Reading and English, were predictors of success in the first semester courses.

Health Education Systems, Inc. (HESI) score was correlated with nursing GPA and NCLEX-RN success but not with timely progression.

GPA as the most recurring student selection method in nursing and other healthcare professions.

Other selection methods include Multiple Mini Interview, Assessment centers, standardized preadmission tests

Relationships between these methods and education outcomes have also been covered.

Statistically significant relationship was established between students' entry critical thinking scores, academic performance and ability to complete the program in 3 years. The strongest predictor of academic failure was students' entry HSRT-test subscale scores. Critical thinking scores had no significant relationship to clinical performance.

A statistically significant relationship was identified between the preprogram GPA, ACT scores, anatomy grades, and the HESI Exit Exam scores with the completion of the BSN program and passing the NCLEX-RN.

WGCTA, prerequisite GPA and NLN had a statistically significant relationship with the nursing GPA. Strongest relationship between prerequisite GPA and the nursing GPA

72 nursing students, 36 lecturers and 5 members of clinical staff from 7

qualitative descriptive design
Staff used a range of attributes (interpersonal skills, team-working, confidence, problem-solving, aptitude for caring, motivations, commitment) as part of holistic assessments. 
Table 1 Study characteristics of included articles $(N=44)$ (Continued)

Author, Purpose
year,
Country,
article type

article type

\begin{tabular}{|c|c|c|c|}
\hline $\begin{array}{l}\text { Wambuguh } \\
\text { et al. } 2016 \text {, } \\
\text { USA [13]. }\end{array}$ & $\begin{array}{l}\text { Report on the Predictability of } \\
\text { Current Admission Criteria for } \\
\text { Nursing Program Success }\end{array}$ & 513 students & $\begin{array}{l}\text { descriptive, } \\
\text { correlational } \\
\text { design }\end{array}$ \\
\hline
\end{tabular}

Research

Current Admission Criteria for

article

Gale et al.

Research

article

Simelane

2017. Africa

[63].

Master of

thesis

Callwood

et al. 2017,

UK [64].

Research

article

Callwood

et al. 2018,

UK [65].

Review

article 2016, UK [6]

To ascertain evidence of bias in Multiple Mini Interviews (MMI), and to determine the predictive value of the MMI of academic success.

to explore nurse educators' perceptions of the current selection criteria and describe the criteria that they would recommend for better selection

To examine the reliability and predictive validity of MMls using end of Year One practice outcomes of under-graduate pre-registration nursing, midwifery and paramedic students

\section{to Identifying personal domains 46 article}

for Nursing Students Selection in

MMl Method

Talma et al. To compare the predictive value 2018, Finland of two on-site selection methods [66]. Research article used in nursing student selection, namely, psychological aptitude tests and literature-based exams

Haavisto et al. 2019,

Finland.

[67]

Research

article

Yousafzai \& To determine the relationship Jamil 2019, between various variables in the Pakistan [68] existing admission criteria and Research academic performance.

article

McNeill et al. Developing nurse match: A 2019, Canada selection tool for evoking and [69]. scoring an applicant's nursing Research values and attributes
204 students who commenced studies in September 2011.

\section{9 participants}

227 student (nursing, midwifery, paramedic)

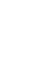

narrative
synthesis
systematic
review

A
longitudinal
retrospective
design

qualitative, exploratory and descriptive design

crossdiscipline cohort study
Findings of this study highlight pre-admission TEAS scores and pre-admit science GPAs as the academic factors that are useful for the selection of students with a higher likelihood of success in nursing school programs, as defined by program completion, graduating with a nursing program GPA of 3.25 or higher, and passing the NCLEX-RN

MMI and MMI numeracy marks appeared to significantly predict academic success (assessment marks). MMI literacy results predicted weakly academic success. MMI showed little or no evidence of bias (gender, age, nationality, location of secondary education).

Necessary criteria for selecting a nursing student include: compassion, empathy, passion, intelligence, caring characteristics, an innate desire to help others, medical monitoring of applicants for chronic illness.

MMls are reliable VBR tools which have predictive validity when a seven station model is used.
626 nursing students

cohort study

\section{cohort study}

3 focus group interviews $(n=26)$ and 39 articles

interpretive descriptive design technology skills, Self-directed skills), Social skills (Ethic-

197 participants

cross sectional study

63 first year nursing students case study- Person Centeredness, Accountability, Trust, Integrity, based qualita- Commitment to Personal Development, Teamwork tive process

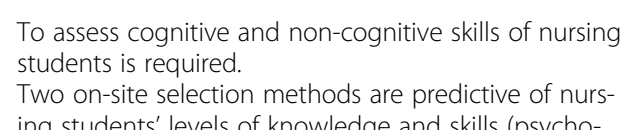
ing students' levels of knowledge and skills (psychological test), and study success (literature based exam) at the beginning of their studies.

Future research should also focus on the admission/ selection costs to universities Learning skills (Language and communication skills, Mathematical skills, reasoning skills, Information ality, Interpersonal Communication, Emotional intelligence), Certainty of career choice (Realistic perception of nursing profession, Desire to work in nursing, Characterizing self as a nurse, Imaging nursing as an ideal career) previous academic scores at diploma level were better predictors of the academic performance

To assess cognitive and non-cognitive skills of nursing students is required.

article 


\section{Results}

Literature search

A total of 5417 articles were found from databases search, duplicate articles were removed, and 3045 articles entered the title and abstract review phase. After excluding unrelated studies, the full text of 182 articles were evaluated in terms of inclusion criteria and 44 articles were included in the final review.

\section{Study characteristics}

Most studies $(n=20)$ were from the USA followed by the UK $(n=9)$, Australia $(n=4)$, Finland $(n=3)$, Canada $(n=3)$ and one study from each of the countries New Zealand, Pakistan, Oman, Sweden, Africa, and Italy. Thirty-two articles were research studies, 4 were review articles and 8 were thesis and doctoral dissertations. Study characteristics are presented in Table 1.

\section{Nursing students' selection criteria}

The Review identified that nursing students are selected based on two criteria: (1) cognitive-academic abilities and (2) non-cognitive abilities. These two criteria are explained below.

\section{Cognitive-academic abilities}

Most studies considered cognitive-academic abilities as an essential criterion for nursing student admission. The four most common cognitive-academic competencies evaluated in nursing applicants included (1) reasoning skills (analysis ability, deductive and inductive reasoning, inference, critical thinking, problem-solving, decision-making evaluation, logic); (2) mathematical skills (math, numeracy, basic calculation, applied math); (3) language skills (English writing, reading comprehension, reading, vocabulary, English reading, general knowledge of the language, word knowledge, literacy, verbal); and (4) natural science skills (chemistry, physics, biology, anatomy and physiology). Nursing applicants were assessed for language and mathematical skills in the majority of studies, and few studies focused on assessing reasoning and natural science skills of nursing applicants (Tables 1 and 3).

\section{Non-cognitive abilities}

Reviewed studies revealed that non-cognitive abilities examined in nursing applicants include communication skills, teamwork, dynamism, morality, psychological strength, Emotional intelligence and warmth (As seen in Table 2).

Methods used to assess nursing student selection criteria Results of the review indicated that two main methods are used to assess the cognitive-academic competencies of nursing applicants are:
1 On-site test for selection (conducted either before or during the Student selection process): According to the reviewed studies, standardized tests are often used to measure cognitive-academic abilities in this method (Table 3).

2 Academic achievement records: In most studies, academic records have been used as the most common criterion for selecting a student for nursing education, typically based on the high school grade point average (GPA) $[8,13,14,32,35$, $37,45,46,49,52,58,61,68]$. Studies have reported prior academic achievement of applicants in general, but it was not possible to further analyze the specific cognitive-academic abilities acquired from academic records of applicants.

Based on the review results, the TEAS was the most commonly used test, yet reliability of test was only confirmed in one study (NDRT test: Nelson-Denny Reading Test) [50]. The reliability or validity of other selection tests reported based on previous assessments by instrument developers in the studies [36, 39, 47, 51, 55, 59, 61]. In other studies, the reliability and validity of the test used was not reported [30, 31, 34, 40, 41, 43, 49, 56, 57, 60].

Four main methods were found to assess the noncognitive abilities of nursing applicants. Interviews (panel interviews or multiple mini interviews) are the main method used to assess communication skills, teamwork morale, ethical insights, and empathy. Personal statements were another selection method, commonly used to assess motivation and self-assessment of personal characteristics. Some nursing institutes also use recommendation letters provided by teachers and there was limited used of personality tests (Table 1 ).

\section{Methods of student selection and relationship with academic performance}

The relationship of selection methods and academic performance was reported positive in 20 articles and neither positive nor negative in 5 articles. The relationship of academic performance with standardized tests (15 articles) and academic records (13 articles) has been examined more than other methods of student selection. Only two articles reported a positive relationship between interviews (individual interview and multiple mini interviews) and academic performance. In most studies, academic success and passing the NCLEX exam (National Council Licensure Examination) have been used as a criterion for assessing academic performance. The relationship between the selection methods (i.e. HSRT: Health Sciences Reasoning Test) and clinical performance has been examined in only one study without identifying a positive or negative relationship (Table 4). 
Table 2 Non-cognitive abilities used in the selection process for nursing students

\begin{tabular}{|c|c|c|c|}
\hline Categories & Definition & Factors & Relevant Studies \\
\hline \multirow[t]{5}{*}{$\begin{array}{l}\text { Communication } \\
\text { skills }\end{array}$} & \multirow[t]{5}{*}{$\begin{array}{l}\text { Collect and convey information in order to } \\
\text { create and sustain relationships with others in } \\
\text { appropriate manner. }\end{array}$} & $\begin{array}{l}\text { appropriate non-verbal } \\
\text { communication/body } \\
\text { language }\end{array}$ & \multirow[t]{5}{*}{$\begin{array}{l}\text { Taylor R et al., } 2014 \text { [52], Waugh A et al., } 2014 \text { [54], } \\
\text { Gale J et al., } 2016 \text { [6], Haavisto E et al., } 2019 \text { [67], } \\
\text { Perkins et al., } 2013 \text { [47], Callwood A et al., } 2018 \text { [65] }\end{array}$} \\
\hline & & active listening & \\
\hline & & expressiveness & \\
\hline & & $\begin{array}{l}\text { Engages in social } \\
\text { conversation }\end{array}$ & \\
\hline & & $\begin{array}{l}\text { Able to give advice, and } \\
\text { give directions to others }\end{array}$ & \\
\hline \multirow[t]{3}{*}{ Teamwork } & \multirow[t]{3}{*}{ Effectively and respectfully work with others } & cooperativeness, & \multirow{3}{*}{$\begin{array}{l}\text { Gale J et al., } 2016 \text { [6], Callwood A et al., } 2018 \text { [65], } \\
\text { Perkins et al., } 2013 \text { [47], Taylor R et al., } 2014 \text { [52], } \\
\text { McNeill C et al., } 2019 \text { [69], Waugh A et al., } 2014 \text { [54] }\end{array}$} \\
\hline & & collegiality & \\
\hline & & $\begin{array}{l}\text { Ability to work closely with } \\
\text { others }\end{array}$ & \\
\hline \multirow[t]{6}{*}{ Dynamism } & \multirow{6}{*}{$\begin{array}{l}\text { Seek for learning opportunities, Flexibility to } \\
\text { change and Being challenging }\end{array}$} & open minded & \multirow{6}{*}{$\begin{array}{l}\text { Haavisto E et al., } 2019 \text { [67], McNeill C et al., } 2019 \text { [69], } \\
\text { Jones-Schenk \& Harper, } 2014 \text { [53] }\end{array}$} \\
\hline & & Self-directed skills & \\
\hline & & $\begin{array}{l}\text { Commitment to Personal } \\
\text { Development }\end{array}$ & \\
\hline & & $\begin{array}{l}\text { adapt to an environment } \\
\text { that may change rapidly }\end{array}$ & \\
\hline & & $\begin{array}{l}\text { Not being resistant to } \\
\text { change, }\end{array}$ & \\
\hline & & adaptability & \\
\hline \multirow[t]{10}{*}{ Morality } & \multirow[t]{10}{*}{$\begin{array}{l}\text { To act in accordance with ethical principles } \\
\text { and standards of conduct }\end{array}$} & $\begin{array}{l}\text { ethical insights (ethical } \\
\text { decision making, moral } \\
\text { judgment) }\end{array}$ & \multirow[t]{10}{*}{$\begin{array}{l}\text { Gale J et al., } 2016 \text { [6], Haavisto E et al., } 2019 \text { [67], } \\
\text { Callwood A et al., } 2018 \text { [65], Jones-Schenk \& Harper, } \\
2014 \text { [53], McNeill C et al., } 2019 \text { [69], Waugh A et al., } \\
2014 \text { [54], Taylor R et al., } 2014 \text { [52] }\end{array}$} \\
\hline & & Responsible & \\
\hline & & Conscientious & \\
\hline & & Accountability & \\
\hline & & Reliable & \\
\hline & & Trustworthy & \\
\hline & & Honesty & \\
\hline & & disclosure e of error & \\
\hline & & integrity & \\
\hline & & $\begin{array}{l}\text { Respect for others (privacy } \\
\text { and dignity) }\end{array}$ & \\
\hline \multirow{4}{*}{$\begin{array}{l}\text { Psychological } \\
\text { strength }\end{array}$} & \multirow[t]{4}{*}{ Ability to deal with the trials and tribulations } & stress management, & \multirow{4}{*}{$\begin{array}{l}\text { Jones-Schenk \& Harper, } 2014 \text { [53], Waugh A et al., } \\
2014 \text { [54] }\end{array}$} \\
\hline & & $\begin{array}{l}\text { tolerance highly stressful } \\
\text { situations }\end{array}$ & \\
\hline & & $\begin{array}{l}\text { able to stand the sight of } \\
\text { blood, able to cope with } \\
\text { death }\end{array}$ & \\
\hline & & Patient & \\
\hline \multirow[t]{4}{*}{$\begin{array}{l}\text { Emotional } \\
\text { intelligence }\end{array}$} & \multirow[t]{4}{*}{$\begin{array}{l}\text { Accurately recognize and understand one's } \\
\text { own emotions and those of others, using this } \\
\text { information to guide future behavior. }\end{array}$} & $\begin{array}{l}\text { emotion perception } \\
\text { (understanding emotions, } \\
\text { Understanding and } \\
\text { supportive) }\end{array}$ & \multirow[t]{4}{*}{$\begin{array}{l}\text { Haavisto E et al., } 2019 \text { [67], Gale J et al., } 2016 \text { [6], } \\
\text { Callwood A et al., } 2018 \text { [65], Taylor R et al., } 2014 \text { [52], } \\
\text { Waugh A et al., } 2014 \text { [54] }\end{array}$} \\
\hline & & $\begin{array}{l}\text { Understand and control } \\
\text { reactions to the behaviors } \\
\text { and emotions of others }\end{array}$ & \\
\hline & & emotional maturity & \\
\hline & & Sensitive to others and self & \\
\hline
\end{tabular}


Table 2 Non-cognitive abilities used in the selection process for nursing students (Continued)

\begin{tabular}{|c|c|c|c|}
\hline Categories & Definition & Factors & Relevant Studies \\
\hline & & $\begin{array}{l}\text { Able to give advice, and } \\
\text { give directions to others }\end{array}$ & \\
\hline \multirow[t]{4}{*}{ Warmth } & \multirow{4}{*}{$\begin{array}{l}\text { Demonstrate affection or enthusiasm in } \\
\text { behavior. }\end{array}$} & Kindness, friendly & \multirow{4}{*}{$\begin{array}{l}\text { Gale J et al., } 2016 \text { [6], Ruth Sampie Simelane } 2017 \\
\text { [63], Callwood A et al., } 2018 \text { [65], Waugh A et al., } \\
2014 \text { [54], Jones-Schenk \& Harper, } 2014 \text { [53], Pitt V } \\
\text { et al., 2012 [42] }\end{array}$} \\
\hline & & Compassionate & \\
\hline & & $\begin{array}{l}\text { Altruistic, (Desire to help, } \\
\text { Inherent desire to care) }\end{array}$ & \\
\hline & & Empathy & \\
\hline
\end{tabular}

\section{Discussion}

This study assessed existing published literature on the admission criteria and selection methods of undergraduate nursing students. Results showed that academiccognitive and non-cognitive abilities are the main two criteria in the process of selecting students for nursing programs. According to the results of this review, the academic-cognitive abilities of the applicants are mainly examined through the academic records and standardized tests, and the non-cognitive abilities are investigated through the interviews, personal statements and references.

Table 3 Onsite selection methods of assessing cognitive-academic abilities

\begin{tabular}{|c|c|}
\hline Name of type of the selection/developer & Items \\
\hline \multicolumn{2}{|l|}{ Standardized tests } \\
\hline $\begin{array}{l}\text { SAT (Scholastic Aptitude Test) } \\
\text { Grossbach \& Kuncel } 2011 \text { [41], Jarmulowicz } 2012 \text { [43], Stuenkel } 2006 \text { [30], } \\
\text { McGahee, Gramling and Reid } 2010 \text { [35] }\end{array}$ & Verbal, math \\
\hline $\begin{array}{l}\text { ACT (American College Test) } \\
\text { Elkins } 2015 \text { [60], Grossbach and Kuncel } 2011 \text { [41], Jarmulowicz } 2012 \text { [43], } \\
\text { McGahee et al. } 2010 \text { [35] }\end{array}$ & English (reading, writing), math, natural science, social science \\
\hline $\begin{array}{l}\text { TEAS (Test of Essential Academic Skills) } \\
\text { Bremner et al. } 2014 \text { [55], Harner } 2014 \text { [56], Hernandez } 2011 \text { [39], Newton } \\
\text { \& Moore } 2009 \text { [34], Newton et al. } 2007 \text { [31], Wolkowitz \& Kelley } 2010 \text { [36] }\end{array}$ & $\begin{array}{l}\text { Reading, mathematics, science (life science, earth science, physical science, } \\
\text { human body science), and English language usage }\end{array}$ \\
\hline $\begin{array}{l}\text { HESI (Health Education Systems Inc) } \\
\text { Hinderer et al. } 2014 \text { [57], Underwood et al. } 2013 \text { [51] }\end{array}$ & $\begin{array}{l}\text { English: reading comprehension, vocabulary \& general knowledge, } \\
\text { grammar. } \\
\text { Math: Basic math skills. } \\
\text { Science: biology, chemistry, anatomy\& physiology, physics }\end{array}$ \\
\hline $\begin{array}{l}\text { HSRT (Health Sciences Reasoning Test) } \\
\text { Pitt et al. } 2015 \text { [59] }\end{array}$ & $\begin{array}{l}\text { Total critical thinking skills, analysis, inference, evaluation, deductive } \\
\text { reasoning and inductive reasoning. }\end{array}$ \\
\hline $\begin{array}{l}\text { NLN (National League for Nursing) } \\
\text { Crouch } 2015 \text { [61], Stuenkel } 2006 \text { [30] }\end{array}$ & $\begin{array}{l}\text { Not stated in the articles. From NLN website (2017): Verbal-Word } \\
\text { knowledge and reading comprehension. Math -Basic calculations, word } \\
\text { problems, applied math. Science-General biology, chemistry, physics and } \\
\text { earth science }\end{array}$ \\
\hline $\begin{array}{l}\text { NET (Nurse Entrance Test) } \\
\text { Herrera } 2012[44]\end{array}$ & Math skills, reading comprehension \\
\hline $\begin{array}{l}\text { NDRT (Nelson-Denny Reading Test) } \\
\text { Lajoie } 2013 \text { [50] }\end{array}$ & Vocabulary, reading comprehension, reading rate. \\
\hline $\begin{array}{l}\text { WGCTA (Watson-Glaser Critical Thinking Appraisal) } \\
\text { Crouch } 2015 \text { [61] }\end{array}$ & Critical thinking \\
\hline \multicolumn{2}{|l|}{ Other selection methods } \\
\hline $\begin{array}{l}\text { Literacy and numeracy test } \\
\text { MacDuff et al. } 2016 \text { [62] }\end{array}$ & Literacy and numeracy skills \\
\hline $\begin{array}{l}\text { MMI (Multiple Mini Interview) } \\
\text { Gale et al. } 2016 \text { [6], MacDuff et al. } 2016 \text { [62], Perkins et al. } 2013 \text { [47], } \\
\text { Timer \& Clauson } 2011 \text { [8] }\end{array}$ & $\begin{array}{l}\text { Cognitive attributes: numeracy skills, literacy skill, decision-making skills, } \\
\text { problem-solving skills }\end{array}$ \\
\hline $\begin{array}{l}\text { Nationwide Entry Exam } \\
\text { Dante et al. } 2011 \text { [40], Lancia et al. } 2013 \text { [49] }\end{array}$ & General education, mathematics, logic, biology, chemistry, physics \\
\hline $\begin{array}{l}\text { Onsite student selection processes: Interview } \\
\text { MacDuff et al. } 2016 \text { [62] }\end{array}$ & Cognitive attributes: problem-solving \\
\hline
\end{tabular}


Review of the selected studies showed that academic abilities of applicants are assessed in three main areas of mathematics, language and natural sciences skills which aligns with the World Health Organization recommendations for selection criteria in nursing students [26]. Basic science skills were suggested in previous studies without any complete explanation. In this study, the most important basic science skills were identified. According to the results of this review, academic abilities are good predictors of academic success of nursing students $[8,39,40,51,56,57,61]$.

Cognitive abilities were another criterion for selecting the nursing student in the reviewed studies. Although the cognitive abilities are very important for all students of the higher education institutions [70], however, the investigation of this criterion among the nursing applicants is of special importance [67]. Cognitive abilities are very crucial in the complex working environments, including the nursing [70]. The nursing field is complex and the undergraduate students must acquire the necessary qualifications for nursing in a relatively short period of time [71]. Therefore, the cognitive preparation is necessary for the individuals to succeed in the theoretical and clinical courses [72]. The research findings also indicate that the nursing applicants who have been investigated according to the reasoning skills have the theoretical and clinical success during their training [59]. The nurses' cognitive abilities play a key role in the problem-solving skills, the clinical decision-making power, and as a results diagnosing the patient needs and selecting the best nursing practices [73, 74]. This could directly affect the patient's safety and improvement [75]. However, the results of this study showed that cognitive abilities of applicants have been assessed in few articles. In this regard, the European Federation of Nurses Association has acknowledged that although this skill is considered an important competence in nursing education, it is usually neglected and under-valued when selecting nursing students [76]. These findings demonstrate the need for assessing reasoning skills for selecting nursing students.

The results of this study showed that the cognitiveacademic abilities of applicants are assessed mainly through academic records or standardized tests [37, 46]. In order to evaluate this ability, the research evidence suggests that the standardized tests and academic records are more relevant to the future academic performance of the nursing students than the other methods (interview and non-standardized tests) $[6,30,36,51,55$, $57,59,61]$, and are better predictors of nursing students' academic success [30, 39]. However, the findings of this study indicated that none of the standardized tests evaluate all of the four cognitive-academic skills in one test. On the other hand, there is little research evidence on the validity and reliability of nursing standardized tests $[30,31,34,46,49,51,56-58,60,61]$. In addition, the most important criticism of using academic records as a selection criterion is heterogeneity of scores, since they are obtained from different institutions, leading to bias in the selection of nursing students [8]. It is worth mentioning that academic records can be a good criterion for students' selection provided that valid standardized tests are nationally conducted.

The non-cognitive skills were another criterion for selecting the nursing student in the reviewed studies. It is important to select nursing students with noncognitive, professionally tailored characteristics to provide safe and high quality care [77]. According to research findings, traits such as empathy and morality of nursing students do not change during their training which highlights the importance of their assessment when entering the nursing profession [78]. Researchers have concluded that academic-cognitive abilities are necessary but not sufficient for becoming a qualified nurse and this criterion alone cannot guarantee ethical and appropriate practice in nursing [66]. Individual values, interests and motivations are not considered in this approach, and individuals with high academic-cognitive abilities cannot be considered competent and qualified nurses merely through education [66]. According to Ones et al., cognitive abilities along with non-cognitive abilities lead to better performance of an individual in a job [79]. Therefore, non-cognitive characteristics should be considered a key criterion in nursing student's selection $[8,66]$.

This review indicates that assessment of non-cognitive abilities is generally done through interview (traditional, multiple mini interview), personal statements, references and personality assessmentt [8, 32, 37, 45, 47]. Interviews are the most common method for assessing noncognitive abilities such as communication and teamwork skills [32, 37, 45, 47, 52, 58], despite evidence that traditional interviews lack predictive validity and are not a powerful tool for selecting nursing students $[8,45,80]$. Interviews are strongly influenced by interviewers [81] and hence are highly associated with bias in the selection process [37]. More recently, some universities have begun using multiple mini interviews to select applicants [47], which have been found to have higher validity and reliability compared to traditional interviews $[47,58]$. However, limited studies exist on the predictive validity of MMI [6, 47]. Construct validity of MMI remains a challenge, and there is insufficient consensus on the dimensions that applicants need to be examined in multiple mini interviews and thus requires further research evidence $[47,52]$. Multiple mini interview is also a costly method because it requires station design as well as more manpower and role players [47, 82, 83]. Personal 
Table 4 The Relationship between student selection methods and academic performance in reviewed studies

\begin{tabular}{|c|c|c|c|c|c|c|}
\hline \multirow[t]{2}{*}{ Selection methods } & \multirow[t]{2}{*}{ Author and years } & \multicolumn{5}{|c|}{$\begin{array}{l}P \text {-value for relationship of student selection methods to academic } \\
\text { performance }\end{array}$} \\
\hline & & $\begin{array}{l}\text { Academic } \\
\text { success }\end{array}$ & Attrition & Graduation & $\begin{array}{l}\text { NCLEX- } \\
\text { RN }\end{array}$ & $\begin{array}{l}\text { Clinical } \\
\text { performance }\end{array}$ \\
\hline \multirow[t]{2}{*}{ American College Test (ACT) } & Elkins 2015 [60] & & & & $<.05 a$ & \\
\hline & $\begin{array}{l}\text { Grossbach \& Kuncel } 2011 \\
\text { [41] }\end{array}$ & & & & $<.01 a$ & \\
\hline \multirow{2}{*}{$\begin{array}{l}\text { Health Education Systems Inc. (HESI) } \\
\text { Admission }\end{array}$} & Hinderer et al. 2014 [57] & $.007 a$ & & Not report & $.01 \mathrm{a}$ & \\
\hline & Underwood et al. 2013 [51] & $<.01 \mathrm{~b}$ & & & & \\
\hline Health Sciences Reasoning Test (HSRT) & Pitt et al. 2015 [59] & $<.01 a$ & & $<.01 \mathrm{~b}$ & & $>.01 \mathrm{~b}$ \\
\hline \multirow[t]{2}{*}{ National League for Nursing (NLN) } & Crouch 2015 [61] & $<.001 \mathrm{a}$ & & & & \\
\hline & Stuenkel 2006 [30] & & & & $<.001 \mathrm{a}$ & \\
\hline \multirow[t]{2}{*}{ Scholastic Aptitude Test (SAT) } & $\begin{array}{l}\text { Grossbach and Kuncel } 2011 \\
\text { [41] }\end{array}$ & & & & $<.01 \mathrm{a}$ & \\
\hline & Stuenkel 2006 [30] & & & & $<.001 a$ & \\
\hline \multirow[t]{7}{*}{ Test of Essential Academic Skills (TEAS) } & Bremner et al. 2014 [55] & $<.001 a$ & & & & \\
\hline & Harner 2014 [56] & $<.001 a$ & & & & \\
\hline & Hernandez 2011 [39] & $<.001 a$ & $<.001 a$ & & & \\
\hline & Newton et al. 2007 [31] & $<.001 \mathrm{a}$ & & & & \\
\hline & Wolkowitz \& Kelley 2010 [36] & $<0.001 b$ & & & & \\
\hline & Newton \& Moore 2009 [34] & & $.329 b$ & & & \\
\hline & Wambuguh et al. 2016 [13] & & & $.01 b$ & $.02 b$ & \\
\hline Watson-Glaser Critical Thinking Appraisal & Crouch 2015 [61] & $<.01 a$ & & & & \\
\hline Nurse Entrance Test (NET) & Herrera 2012 [44] & & & $>.01 \mathrm{~b}$ & & \\
\hline \multirow[t]{2}{*}{ Nationwide Entry Exam } & Dante et al. 2011 [40] & $.006 \mathrm{~b}$ & & $.001 b$ & & \\
\hline & Lancia et al. 2013 [49] & $.38 \mathrm{a}$ & & $.215 a$ & & \\
\hline \multirow[t]{13}{*}{ Previous academic achievement } & Newton et al. 2007 [31] & $<.001 \mathrm{~b}$ & & & & \\
\hline & Newton \& Moore 2009 [34] & $<.001 \mathrm{a}$ & & & & \\
\hline & Lancia et al. 2013 [49] & $.001 \mathrm{a}$ & & $.001 \mathrm{a}$ & & \\
\hline & Crouch 2015 [61] & $<.01 \mathrm{a}$ & & & & \\
\hline & Timer \& Clauson 2011 [8] & $<.001 \mathrm{~b}$ & & & & \\
\hline & Wambuguh et al. 2016 [13] & $.001 b$ & & $.01 a$ & & \\
\hline & Elkins 2015 [60] & & & $<.01 a$ & $<.01 a$ & \\
\hline & Herrera 2012 [44] & & & $<.001 \mathrm{a}$ & & \\
\hline & $\begin{array}{l}\text { Schmidt \& MacWilliams } 2011 \\
\text { [37] }\end{array}$ & & & $<.01 a$ & $<.01 \mathrm{a}$ & \\
\hline & Hernandez 2011 [39] & & & $<.01 a$ & $<.01 \mathrm{a}$ & \\
\hline & $\begin{array}{l}\text { Grossbach \& Kuncel } 2011 \\
\text { [41] }\end{array}$ & & & & $<.01 a$ & \\
\hline & Stuenkel 2006 [30] & & & & $<.01 a$ & \\
\hline & McGahee et al. 2010 [35] & & & & $.002 \mathrm{a}$ & \\
\hline \multirow[t]{2}{*}{ Interviews } & Gale et al. 2016 [6] & $.03 b$ & & & & \\
\hline & $\begin{array}{l}\text { Schmidt \& MacWilliams } 2011 \\
\text { [37] }\end{array}$ & & $<.01 \mathrm{~b}$ & & & \\
\hline
\end{tabular}


statements are another method used to assess noncognitive characteristics including motivation and selfevaluation $[8,45]$. There is little research evidence to confirm the predictive validity of personal statements, and most research evidence indicates that this method lacks validity and reliability as a selection tool $[8,45,46$, 52]. On the other hand, the content of personal statements may lead to unfair judgment in the selection of applicants [84]. There is limited studies regarding the use of references as a student selection method and their use is not recommended due to low reliability and validity $[8,46,52]$. Despite these findings, most nursing schools widely use personal statements and references for student selection. Some studies have suggested personality assessment to assess non-cognitive abilities. The results of a Meta-analysis on the predictive validity of personality assessment showed an insignificant relationship between personality predictors and job criteria [79]. Despite low validity, these tests have been widely used in selecting health care professionals for many years [85].

In addition to the above-mentioned methods, selection centers and situational judgment tests are also used for assessing the non-cognitive abilities suggested for medical students. Research evidence regarding the use of selection centers for selecting medical applicants indicates high validity of this method, but it can be costly for institutions [86, 87]. Situational judgment tests have also been recognized as a reliable valid method for assessing non-cognitive abilities and are used to examine a wide range of non-cognitive traits for selecting many largescale job applicants $[88,89]$. Despite the use of situational judgment tests for student selection in some health care professions [90-94], no research evidence was found regarding the use of this method for nursing student selection.

\section{Limitations}

The findings of this scoping review must be interpreted with caution because the quality of the selected articles was not evaluated. Therefore, articles of varying quality were included in this study and the results may be of limited reliability.

\section{Conclusion}

The results of this scoping review can be used by nursing education policymakers and institutes for comprehensive assessment of applicants in terms of their suitability for the nursing education. Both academiccognitive and non-cognitive abilities should be considered when selecting a student for entry into nursing education. Future studies should be directed toward assessing and improving methods of student selection. According to the reviewed studies, there is limited evidence on content and predictive validity of selection methods including MMIs and standardized tests. Longitudinal studies (examining students during the course of study and career) are required to assess predictive validity of these methods. The findings of this review showed insufficient consensus among researchers about which non-cognitive characteristics should be examined in nursing applicants. Further research is required to identify attributes considered essential for success during nursing training and nursing practice. The relative contribution of each selection criterion in the student admission system is also unclear; therefore, further research is needed to weigh the selection criteria. Given the lack of research evidence on the situational judgment tests in nursing education despite its costeffectiveness and large-scale feasibility, it is suggested to design these tests to examine the non-cognitive characteristics of applicants.

\section{Supplementary Information}

The online version contains supplementary material available at https://doi. org/10.1186/s12912-020-00510-1.

Additional file 1. Preferred Reporting Items for Systematic reviews and Meta-Analyses extension for Scoping Reviews (PRISMA-SCR) Checklist.

\begin{abstract}
Abbreviations
GPA: Grade point average; NDRT: Nelson-Denny Reading Test; NCLEX: National Council Licensure Examination; ACT: American College Test; TEAS: Test of essential academic skills; HSRT: Health Sciences Reasoning Test; HESI: Health Education Systems Inc; MMI: Multiple mini interview; BSN: Bachelor of Science in Nursing; NLN: National League for Nursing; RN: Registered Nurse; NCEA: National Certificate of Educational Achievement; SAT: Scholastic Achievement Test; NET: Nurse Entrance Test; WGCTA: WatsonGlaser Critical Thinking Appraisal
\end{abstract}

\section{Acknowledgments}

The authors wish to thank all researchers whose articles were used in this review study. We wish to acknowledge the contribution of the external consultant, Professor Fiona Patterson of the University of Cambridge, and Emma Morley at Work Psychology Group who advise and feedback greatly improved this manuscript.

\section{Authors' contributions}

VZ: concept design, data collection, analysis and interpretation, drafting of manuscript; AG: participated in the study design, data collection and analysis, manuscript revision; LV: participated in the study design and analysis; FB: data collection, analysis and interpretation, drafting of manuscript; ML: analysis and interpretation, critical revision of manuscript. All authors read and approved the final manuscript.

\section{Funding}

This study was financially supported by Tabriz University of Medical Sciences. The funding part had no role in the design of the study, the collection, analysis and interpretation of the data, or in writing the manuscript.

\section{Availability of data and materials}

The datasets used and/or analysed the current study are available from the corresponding author upon reasonable request.

Ethics approval and consent to participate

Approval code of ethics with number: IR.TBMED.REC.1397.583.

Consent to participate: Not applicable 


\section{Consent for publication}

Not applicable.

\section{Competing interests}

None of the authors had a conflict of interest.

\section{Author details}

'Department of Medical Surgical Nursing, School of Nursing and Midwifery, Tabriz University of Medical Sciences, Tabriz, Iran. ${ }^{2}$ Department of Pediatric Nursing, School of Nursing and Midwifery, Tabriz University of Medical Sciences, Tabriz, Iran. ${ }^{3}$ School of Medicine \& Public Health, University of Newcastle, Hunter Medical Research Institute (HMRI), Newcastle, Australia.

\section{Received: 26 May 2020 Accepted: 29 November 2020}

\section{Published online: 14 December 2020}

\section{References}

1. Patterson F, Griffin B, Hanson MD. Opening editorial: selection and recruitment in medical education. MedEdPublish. 2018;7. https://doi.org/10. 15694/mep.2018.0000222.1.

2. Mahon KE, Henderson MK, Kirch DG. Selecting tomorrow's physicians: the key to the future health care workforce. Acad Med. 2013;88(12):1806-11. https://doi.org/10.1097/ACM.0000000000000023.

3. Ezeala CC, Ezeala MO, Swami N. Strengthening the admissions process in health care professional education: focus on a premier Pacific Island medical college. J Educ Eval Health Prof. 2012;9(11). https://doi.org/10.3352/ jeehp.2012.9.11.

4. Smiley RA, Lauer P, Bienemy C, Berg JG, Shireman E, Reneau KA, et al. The 2017 national nursing workforce survey. J Nurs Regul. 2018;9(3):S1-S88. https://doi.org/10.1016/S2155-8256(18)30131-5

5. World Health Organization. Global age-friendly cities: a guide. World Health Organization; 2007. https://apps.who.int/iris/handle/10665/43755.

6. Gale J, Ooms A, Grant R, Paget K, Marks-Maran D. Student nurse selection and predictability of academic success: the Multiple Mini Interview project. Nurse Educ Today. 2016;40:123-7. https://doi.org/10.1016/j.nedt.2016.01.031.

7. Wilson A, Chur-Hansen A, Marshall A, Air T. Should nursing-related work experience be a prerequisite for acceptance into a nursing programme?: a study of students' reasons for withdrawing from undergraduate nursing at an Australian university. Nurse Educ Today. 2011;31(5):456-60. https://doi. org/10.1016/j.nedt.2010.09.005.

8. Timer JE, Clauson MI. The use of selective admissions tools to predict students' success in an advanced standing baccalaureate nursing program. Nurse Educ Today. 2011:31(6):601-6. https://doi.org/10.1016/.j.nedt.2010.10.015.

9. Rankin B. Emotional intelligence: enhancing values-based practice and compassionate care in nursing. J Adv Nurs. 2013;69(12):2717-25. https://doi. org/10.1111/jan.12161.

10. Wood C. Choosing the 'right'people for nursing: can we recruit to care? $\mathrm{Br}$ J Nurs. 2014;23(10):528-30. https://doi.org/10.12968/bjon.2014.23.10.528.

11. Codier E. Emotional intelligence: enhancing value-based practice and compassionate care in nursing. Evid Based Nurs. 2015;18(1):8. https://doi org/10.1136/eb-2014-101733.

12. Francis R. Report of the Mid Staffordshire NHS Foundation Trust public inquiry: executive summary. London: Stationery Office; 2013.

13. Wambuguh $\mathrm{O}$, Eckfield M, Van Hofwegen L. Examining the importance of admissions criteria in predicting nursing program success. Int J Nurs Educ Scholarsh. 2016;13(1):87-96. https://doi.org/10.1515/ijnes-2015-0088.

14. Ahmad MM, Safadi RR. Entry criteria and nursing students' success. Jordan Med J. 2009:43(3):189-95.

15. Esmaeili M, Dehghan-Nayeri N, Negarandeh R. A review of the opportunities and challenges facing the nursing associations in Iran. Int Nurs Rev. 2012; 59(2):168-74. https://doi.org/10.1111/j.1466-7657.2012.00981.x.

16. Azizi Fl. Nursing challenges in Iran. Nurs Midwif Stud. 2014;3(2):e19906. https://doi.org/10.17795/nmsjournal19906

17. Farrokhi-Khajeh-Pasha Y, Nedjat S, Mohammadi A, Rad EM, Majdzadeh R, Monajemi F, et al. The validity of Iran's national university entrance examination (Konkoor) for predicting medical students' academic performance. BMC Med Educ. 2012;12(1):60. https://doi.org/10.1186/14726920-12-60.

18. Nedjat S, Bore M, Majdzadeh R, Rashidian A, Munro D, Powis D, et al. Comparing the cognitive, personality and moral characteristics of high school and graduate medical entrants to the Tehran University of Medical Sciences in Iran. Med Teach. 2013;35(12):e1632-e7.

19. Tayebi Z, Dehghan-Nayeri N, Negarandeh R, Shahbazi S. Motives for entering nursing in Iran: a qualitative study. Iran J Nurs Midwifery Res. 2013; 18(1):59.

20. Khomeiran RT, Deans C. Nursing education in Iran: past, present, and future. Nurse Educ Today. 2007;27(7):708-14. https://doi.org/10.1016/j.nedt.2006.10. 003.

21. Ahmadi MS. Predicting job stress and burnout based on personality characteristics of nurses. Knowledge Res Appl Psychol. 2016:17(2):99-107.

22. Farsi Z, Dehghan-Nayeri N, Negarandeh R, Broomand S. Nursing profession in Iran: an overview of opportunities and challenges. Jpn J Nurs Sci. 2010; 7(1):9-18. https://doi.org/10.1111/j.1742-7924.2010.00137.x.

23. Atashzadeh Shoorideh F, Rasouli M, Zagheri Tafreshi M. Nurses' turnover process: a qualitative research. J Qual Res Health Sci. 2014:3(1):62-79.

24. Creech CJ, Aplin-Kalisz C. Developing a selection method for graduate nursing students. J Am Acad Nurse Pract. 2011;23(8):404-9. https://doi.org/ 10.1111/j.1745-7599.2011.00626.x

25. Callwood A, Allan H, Courtenay M. Are current strategies for pre-registration student nurse and student midwife selection 'fit for purpose' from a UK perspective? Introducing the multiple mini interview. Nurse Educ Today. 2012;32(8):835-7. https://doi.org/10.1016/j.nedt.2012.05.019.

26. World Health Organization (WHO): Nursing \& Midwifery: Human Resources for Health Global standards for the initial education of professional nurses and midwives. 2009, From: http://www.who.int/hrh/nursing_midwifery/hrh_ global_standards_education.pdf. Accessed 20 Jan 2010.

27. Khalil H, Peters M, Godfrey CM, Mclnerney P, Soares CB, Parker D. An evidence-based approach to scoping reviews. Worldviews Evid-Based Nurs. 2016;13(2):118-23. https://doi.org/10.1111/wvn.12144.

28. Levac D, Colquhoun H, O'Brien KK. Scoping studies: advancing the methodology. Implement Sci. 2010;5(1):69. https://doi.org/10.1186/17485908-5-69.

29. Arksey H, O'Malley L. Scoping studies: towards a methodological framework Int J Soc Res Methodol. 2005;8(1):19-32. https://doi.org/10.1080/ 1364557032000119616

30. Stuenkel DL. At-risk students: do theory grades+ standardized examinations= success? Nurse Educ. 2006;31(5):207-12. https://doi.org/10. 1097/00006223-200609000-00007.

31. Newton SE, Smith LH, Moore G, Magnan M. Predicting early academic achievement in a baccalaureate nursing program. J Prof Nurs. 2007;23(3): 144-9. https://doi.org/10.1016/j.profnurs.2006.07.001.

32. Hayes $L$. Recruitment strategies for baccalaureate nursing students in Ontario. J Nurs Educ. 2007;46(6):261-8. https://doi.org/10.3928/0148483420070601-05.

33. Whitehead $E_{1}$ Mason $T$, Ellis J. The future of nursing: career choices in potential student nurses. Br J Nurs. 2007;6(8):491-6. https://doi.org/10. 12968/bjon.2007.16.8.23422.

34. Newton SE, Moore G. Use of aptitude to understand bachelor of science in nursing student attrition and readiness for the National Council Licensure Examination-Registered Nurse. J Prof Nurs. 2009;25(5):273-8. https://doi.org/ 10.1016/j.profnurs.2009.01.016.

35. McGahee TW, Gramling L, Reid T. NCLEX-RN success: are there predictors. South Online J Nurs Res. 2010:10(4):208-21.

36. Wolkowitz AA, Kelley JA. Academic predictors of success in a nursing program. J Nurs Educ. 2010;49(9):498-503. https://doi.org/10.3928/0148483420100524-09.

37. Schmidt B, MacWilliams B. Admission criteria for undergraduate nursing programs: a systematic review. Nurse Educ. 2011;36(4):171-4. https://doi. org/10.1097/NNE.0b013e31821fdb9d.

38. Shulruf B, Wang YG, Zhao YJ, Baker $H$. Rethinking the admission criteria to nursing school. Nurse Educ Today. 2011;31(8):727-32. https://doi.org/10. 1016/j.nedt.2010.11.024.

39. Hernandez M. Correlating quantitative nursing preadmission variables, ATI test results, and program outcomes including retention, graduation, and licensure. PhD thesis. Northern Illinois University; 2011.

40. Dante A, Valoppi G, Saiani L, Palese A. Factors associated with nursing students' academic success or failure: a retrospective Italian multicenter study. Nurse Educ Today. 2011;31(1):59-64. https://doi.org/10.1016/j.nedt. 2010.03.016

41. Grossbach A, Kuncel NR. The predictive validity of nursing admission measures for performance on the national council licensure examination: a 
meta-analysis. J Prof Nurs. 2011;27(2):124-8. https://doi.org/10.1016/j. profnurs.2010.09.010

42. Pitt $V$, Powis $D$, Levett-Jones $T$, Hunter $S$. Factors influencing nursing students' academic and clinical performance and attrition: an integrative literature review. Nurse Educ Today. 2012;32(8):903-13. https://doi.org/10. 1016/j.nedt.2012.04.011.

43. Jarmulowicz MA. Assessment of admission criteria and selection process for nurse education programs. PhD thesis. University of Walden; 2012.

44. Herrera C. Student retention in higher education: examining the patterns of selection, preparation, retention, and graduation of nursing students in the undergraduate pre-licensure nursing program. PhD thesis. Arizona State University; 2012

45. Rodgers S, Stenhouse R, McCreaddie M, Small P. Recruitment, selection and retention of nursing and midwifery students in Scottish Universities. Nurse Educ Today. 2013;33(11):1301-10. https://doi.org/10.1016/.nedt.2013.02.024.

46. Ruth-Sahd LA. A call to action: nursing education must embrace change and move forward. Dimens Crit Care Nurs. 2014;33(1):28-33. https://doi.org/ 10.1097/DCC.0000000000000020.

47. Perkins A, Burton L, Dray B, Elcock K. Evaluation of a multiple-mini-interview protocol used as a selection tool for entry to an undergraduate nursing programme. Nurse Educ Today. 2013;33(5):465-9. https://doi.org/10.1016/j. nedt.2012.04.023.

48. Usher K, West C, MacManus M, Waqa S, Stewart L, Henry R, et al. Motivations to nurse: an exploration of what motivates students in Pacific Island countries to enter nursing. Int J Nurs Pract. 2013;19(5):447-54. https:// doi.org/10.1111/ijn.12095.

49. Lancia L, Petrucci C, Giorgi F, Dante A, Cifone MG. Academic success or failure in nursing students: results of a retrospective observational study. Nurse Educ Today. 2013;33(12):1501-5. https://doi.org/10.1016/j.nedt.2013. 05.001.

50. Lajoie DL. Reading comprehension and nursing education: a missing variable associated with nursing student attrition?. PhD thesis. University of Wisconsin-Milwaukee; 2013

51. Underwood LM, Williams LL, Lee MB, Brunnert KA. Predicting baccalaureate nursing students' first-semester outcomes: Hesi admission assessment. J Prof Nurs. 2013;29(2):S38-42. https://doi.org/10.1016/j.profnurs.2012.07.003.

52. Taylor R, Macduff C, Stephen A. A national study of selection processes for student nurses and midwives. Nurse Educ Today. 2014;34(8):1155-60. https://doi.org/10.1016/j.nedt.2014.04.024.

53. Jones-Schenk J, Harper MG. Emotional intelligence: an admission criterion alternative to cumulative grade point averages for prelicensure students. Nurse Educ Today. 2014;34(3):413-20. https://doi.org/10.1016/j.nedt.2013.03.018.

54. Waugh A, Smith D, Horsburgh D, Gray M. Towards a values-based person specification for recruitment of compassionate nursing and midwifery candidates: a study of registered and student nurses' and midwives' perceptions of prerequisite attributes and key skills. Nurse Educ Today. 2014; 34(9):1190-5. https://doi.org/10.1016/j.nedt.2013.12.009.

55. Bremner MN, Blake BJ, Long JM, Yanosky DJ. Setting a benchmark for the test of essential academic skills (TEAS) V: striving for first-semester success in nursing school. J Nurs Educ. 2014;53(9):537-40. https://doi.org/10.3928/ 01484834-20140821-12.

56. Harner A. Components of the test of essential academic skills as a predictor of first year success in a baccalaureate nursing program. PhD thesis. University of Florida Gulf Coast; 2014.

57. Hinderer KA, DiBartolo MC, Walsh CM. HESI admission assessment (A2) examination scores, program progression, and NCLEX-RN success in baccalaureate nursing: an exploratory study of dependable academic indicators of success. J Prof Nurs. 2014;30(5):436-42. https://doi.org/10.1016/ j.profnurs.2014.01.007.

58. Sanneh L, Mbuiya A. Use of different selection methods in nursing education and other healthcare professions: a literature review. Bachelor theses. Helsinki Metropolia University of Applied Sciences; 2015.

59. Pitt $V$, Powis $D$, Levett-Jones $T$, Hunter $S$. The influence of critical thinking skills on performance and progression in a pre-registration nursing program. Nurse Educ Today. 2015;35(1):125-31. https://doi.org/10.1016/j. nedt.2014.08.006.

60. Elkins N. Predictors of retention and passing the national council licensure examination for registered nurses. Open J Nurs. 2015;5(03):218-25. https:// doi.org/10.4236/ojn.2015.53026.

61. Crouch SJ. Predicting success in nursing programs. J Coll Teach Learn. 2015; 12(1):45-54. https://doi.org/10.19030/tlc.v12i1.9069.
62. Macduff C, Stephen A, Taylor R. Decision precision or holistic heuristic?: insights on on-site selection of student nurses and midwives. Nurse Educ Pract. 2016;16(1):40-6. https://doi.org/10.1016/j.nepr.2015.06.008.

63. Simelane RS. Perceptions of nurse educators regarding selection criteria of first-year nursing students in the West Rand Region Nursing College. Master's thesis. University of South Africa; 2017.

64. Callwood A, Cooke D, Bolger S, Lemanska A, Allan H. The reliability and validity of multiple mini interviews (MMIs) in values based recruitment to nursing, midwifery and paramedic practice programmes: findings from an evaluation study. Int J Nurs Stud. 2018;77:138-44. https://doi.org/10.1016/j. ijnurstu.2017.10.003.

65. Callwood A, Jeevaratnam K, Kotronoulas G, Schneider A, Lewis L, Nadarajah VD. Personal domains assessed in multiple mini interviews (MMls) for healthcare student selection: a narrative synthesis systematic review. Nurse Educ Today. 2018;64:56-64. https://doi.org/10.1016/j.nedt.2018.01.016.

66. Talman K, Hupli M, Puukka P, Leino-Kilpi H, Haavisto E. The predictive value of two on-site selection methods of undergraduate nursing students: a cohort study. J Nurs Educ Pract. 2018;8(7):12-21. https://doi.org/10.5430/ jnep.v8n7p12

67. Haavisto E, Hupli M, Hahtela N, Heikkilä A, Huovila P, Moisio E-L, et al. Structure and content of a new entrance exam to select undergraduate nursing students. Int J Nurs Educ Scholarsh. 2019;16(1):1-15. https://doi.org/ 10.1515/ijnes-2018-0008.

68. Yousafzai II, Jamil B. Relationship between admission criteria and academic performance: a correlational study in nursing students. Pak J Med Sci. 2019; 35(3):858-61. https://doi.org/10.12669/pjms.35.3.217.

69. McNeill C, Erskine A, Ellis R, Traynor M. Developing nurse match: a selection tool for evoking and scoring an applicant's nursing values and attributes. Nurs Open. 2019;6(1):59-71. https://doi.org/10.1002/nop2.183.

70. Ghanizadeh A. The interplay between reflective thinking, critical thinking, self-monitoring, and academic achievement in higher education. High Educ. 2017;74(1):101-14. https://doi.org/10.1007/s10734-016-0031-y.

71. American Nurses Association (ANA). Nursing: scope and standards of practice. 2nd ed. Maryland: Silver Spring, MD; 2010.

72. McNelis AM, Wellman DS, Krothe JS, Hrisomalos DD, McElveen JL, South RJ. Revision and evaluation of the Indiana University School of Nursing baccalaureate admission process. J Prof Nurs. 2010;26(3):188-95. https://doi. org/10.1016/.jprofnurs.2010.01.003.

73. Chan ZC. A systematic review of critical thinking in nursing education. Nurse Educ Today. 2013;33(3):236-40. https://doi.org/10.1016/..nedt.2013.01.007.

74. Kerman Saravi F, Rigi N, Dokht S, Ebrahimy TE. Critical thinking skills in Zahedan University of Medical Sciences freshman nursing students and graduated in 2009-2011. J Qual Res Health Sci. 2011;11(1and 2):7-17.

75. Simmons B. Clinical reasoning: concept analysis. J Adv Nurs. 2010;66(5): 1151-8. https://doi.org/10.1111/j.1365-2648.2010.05262.x.

76. European Federation of Nurses Associations (EFN). EFN Guideline for the Implementation of ARTICLE 31 of the Mutual Recognition of Professional Qualifications Directive 2005/36/EC, Amended by Directive 2013/55/EU. EFN Competency Framework Adopted at the EFN General Assembly, April 2015, Brussels. 2015. http://www.efnweb.be/wp-content/uploads/EFNCompetency-Framework-19-05-2015.pdf. Accessed 16 Sept 2019.

77. Patterson F, Ferguson E, Thomas S. Using job analysis to identify core and specific competencies: implications for selection and recruitment. Med Educ. 2008;42(12):1195-204. https://doi.org/10.1111/j.1365-2923.2008.03174.x.

78. Pitt $\mathrm{V}$, Powis $\mathrm{D}$, Levett-Jones T, Hunter S. Nursing students' personal qualities: a descriptive study. Nurse Educ Today. 2014;34(9):1196-200. https://doi.org/10.1016/j.nedt.2014.05.004.

79. Ones DS, Dilchert S, Viswesvaran C, Judge TA. In support of personality assessment in organizational settings. Pers Psychol. 2007;60(4):995-1027. https://doi.org/10.1111/j.1744-6570.2007.00099.x.

80. Salvatori P. Reliability and validity of admissions tools used to select students for the health professions. Adv Health Sci Educ. 2001;6(2):159-75. https://doi.org/10.1023/A:1011489618208.

81. Quintero AJ, Segal LS, King TS, Black KP. The personal interview: assessing the potential for personality similarity to bias the selection of orthopaedic residents. Acad Med. 2009;84(10):1364-72. https://doi.org/10.1097/ACM. Ob013e3181b6a9af.

82. Rosenfeld JM, Reiter HI, Trinh K, Eva KW. A cost efficiency comparison between the multiple mini-interview and traditional admissions interviews. Adv Health Sci Educ. 2008;13(1):43-58. https://doi.org/10.1007/s10459-0069029-z. 
83. Eva KW, Reiter HI, Trinh K, Wasi P, Rosenfeld J, Norman GR. Predictive validity of the multiple mini-interview for selecting medical trainees. Med Educ. 2009;43(8):767-75. https://doi.org/10.1111/j.1365-2923.2009.03407.x.

84. Kumwenda B, Dowell J, Husbands A. Is embellishing UCAS personal statements accepted practice in applications to medicine and dentistry? Med Teach. 2013;35(7):599-603. https://doi.org/10.3109/0142159X.2013. 798402.

85. Hojat M, Erdmann JB, Gonnella JS. Personality assessments and outcomes in medical education and the practice of medicine: AMEE guide no. 79. Med Teach. 2013;35(7):e1267-e301. https://doi.org/10.3109/0142159X.2013. 785654.

86. Ziv A, Rubin O, Moshinsky A, Gafni N, Kotler M, Dagan Y, et al. MOR: a simulation-based assessment centre for evaluating the personal and interpersonal qualities of medical school candidates. Med Educ. 2008;42(10): 991-8. https://doi.org/10.1111/j.1365-2923.2008.03161.x.

87. Smal K. Educational assessment center techniques for entrance selection in medical school. Acad Med. 2002;77(7):737. https://doi.org/10.1097/ 00001888-200207000-00022.

88. Lievens F, Peeters H, Schollaert E. Situational judgment tests: a review of recent research. Pers Rev. 2008;37(4):426-41. https://doi.org/10.1108/ 00483480810877598.

89. Patterson F, Ashworth V, Zibarras L, Coan P, Kerrin M, O'Neill P. Evaluations of situational judgement tests to assess non-academic attributes in selection. Med Educ. 2012;46(9):850-68. https://doi.org/10.1111/j.1365-2923. 2012.04336.x.

90. Luschin-Ebengreuth M, Dimai HP, Ithaler D, Neges HM, Reibnegger G. Situational judgment test as an additional tool in a medical admission test: an observational investigation. BMC Res Notes. 2015;8(1):81. https://doi.org/ 10.1186/s13104-015-1033-z

91. Patterson F, Galbraith K, Flaxman C, Kirkpatrick CM. Evaluation of a situational judgement test to develop non-academic skills in pharmacy students. Am J Pharm Educ. 2019;83(10):7074. https://doi.org/10.5688/ ajpe7074.

92. Rowett E, Patterson F, Cousans F, Elley K. Using a situational judgement test for selection into dental core training: a preliminary analysis. Br Dent J. 2017; 222(9):715. https://doi.org/10.1038/sj.bdj.2017.410.

93. Taylor N, Mehra S, Elley K, Patterson F, Cousans F. The value of situational judgement tests for assessing non-academic attributes in dental selection. Br Dent J. 2016;220(11):565-6. https://doi.org/10.1038/sj.bdj.2016.406.

94. Smith DT, Tiffin PA. Evaluating the validity of the selection measures used for the UK's foundation medical training programme: a national cohort study. BMJ Open. 2018;8(7):e021918. https://doi.org/10.1136/bmjopen-201802191.

\section{Publisher's Note}

Springer Nature remains neutral with regard to jurisdictional claims in published maps and institutional affiliations.

Ready to submit your research? Choose BMC and benefit from:

- fast, convenient online submission

- thorough peer review by experienced researchers in your field

- rapid publication on acceptance

- support for research data, including large and complex data types

- gold Open Access which fosters wider collaboration and increased citations

- maximum visibility for your research: over $100 \mathrm{M}$ website views per year

At BMC, research is always in progress.

Learn more biomedcentral.com/submissions 